\title{
Niche specialization of bacteria in permanently ice-covered lakes of the McMurdo Dry Valleys, Antarctica
}

\section{Authors: Miye Kwon, Mincheol Kim, Cristina Takacs- Vesbach, Jaejin Lee, Soon Gyu Hong, Sang Jong Kim, John C Priscu, and Ok-Sun Kim}

This is the peer reviewed version of the following article: [Kwon, Miye, Mincheol Kim, Cristina Takacs-Vesbach, Jaejin Lee, Soon Gyu Hong, Sang Jong Kim, John C. Priscu, and Ok-Sun Kim. "Niche specialization of bacteria in permanently ice-covered lakes of the McMurdo Dry Valleys, Antarctica." Environmental Microbiology (April 2017). DOI: 10.1111/1462-2920.13721.], which has been published in final form at https://dx.doi.org/10.1111/1462-2920.13721. This article may be used for non-commercial purposes in accordance with Wiley Terms and Conditions for Self-Archiving. 


\section{Niche specialization of bacteria in permanently ice-covered lakes of the McMurdo Dry Valleys, Antarctica}

Miye Kwon, ${ }^{1,2 \dagger}$ Mincheol Kim, ${ }^{1 \dagger}$

Cristina Takacs-Vesbach, ${ }^{3}$ Jaejin Lee, ${ }^{1}$

Soon Gyu Hong, ${ }^{1}$ Sang Jong Kim, ${ }^{2}$

John C Priscu ${ }^{4 *}$ and Ok-Sun Kim ${ }^{1 \star *}$

${ }^{1}$ Division of Polar Life Sciences, Korea Polar Research

Institute, Incheon 21990, Republic of Korea.

${ }^{2}$ School of Biological Sciences, Seoul National

University, Seoul 08826, Republic of Korea.

${ }^{3}$ Department of Biology, University of New Mexico, Albuquerque, NM, 87043, USA.

${ }^{4}$ Department of Land Resources and Environmental Sciences, Montana State University, Bozeman, MT, 59717, USA.

\section{Summary}

Perennially ice-covered lakes in the McMurdo Dry Valleys, Antarctica, are chemically stratified with depth and have distinct biological gradients. Despite longterm research on these unique environments, data on the structure of the microbial communities in the water columns of these lakes are scarce. Here, we examined bacterial diversity in five ice-covered Antarctic lakes by 16S rRNA gene-based pyrosequencing. Distinct communities were present in each lake, reflecting the unique biogeochemical characteristics of these environments. Further, certain bacterial lineages were confined exclusively to specific depths within each lake. For example, candidate division WM88 occurred solely at a depth of $15 \mathrm{~m}$ in Lake Fryxell, whereas unknown lineages of Chlorobi were found only at a depth of $18 \mathrm{~m}$ in Lake Miers, and two distinct classes of Firmicutes inhabited East and West Lobe Bonney at depths of $30 \mathrm{~m}$. Redundancy analysis revealed that community variation of bacterioplankton could be explained by the distinct conditions of each lake and depth; in particular, assemblages from layers beneath the chemocline had biogeochemical associations that differed from those in the upper layers. These patterns of community composition may represent bacterial adaptations to the extreme and unique biogeochemical gradients of ice-covered lakes in the McMurdo Dry Valleys.

\section{Introduction}

The McMurdo Dry Valleys (MDVs), located in Southern Victoria Land, Antarctica, form the coldest and driest desert on Earth. The MDVs are exposed to severe environmental conditions, characterised by a mean annual temperature below $0^{\circ} \mathrm{C}$, high levels of ultraviolet radiation, extremely low precipitation, extended periods of darkness, frequent freeze-thaw cycles and attenuated photosynthetically active radiation (PAR) (Lizotte and Priscu, 1994; Fountain et al., 1999). Despite these conditions, numerous perennially ice-covered (3-6 $\mathrm{m}$ ice thickness) lakes occur across the valleys, most of which are chemically stratified and have no outflows. The permanent ice cover inhibits wind-induced turbulence, which, together with strong chemical stratification, results in extremely stable water columns with little vertical mixing (Priscu, 1995; Spigel and Priscu, 1998;). Bowman et al. (2016) demonstrated that these lakes are moderately productive, and contain a diverse group of microplanktonic prokaryotes and eukaryotes.

The lakes of the MDVs have been isolated from one another and from exchange with the atmosphere owing to their perennial ice cover for perhaps thousands of years (Lyons et al., 1998; Poreda et al., 2004). The strong chemoclines in many of the lakes effectively isolate the deep saline waters from the fresh surface waters (Spigel and Priscu, 1998). The deep saline waters of these lakes are often suboxic and contain unique geochemistries (Priscu, 1997; Lee et al., 2004; Priscu et al., 2008). These unique lake systems are dominated by bacteria, which comprise $30-60 \%$ of the total microplankton biomass (Takacs and Priscu, 1998). Bacterial production is highest immediately beneath the ice cover, with a second production peak occuring near the chemocline (Takacs and Priscu, 1998). 
The microbial diversity of the MDV lakes has been surveyed using culture-dependent approaches (Karr et al., 2003; Sattley and Madigan, 2006), and more recently by culture-independent methods such as DNA fingerprinting (e.g., DGGE, t-RFLP), cloning/sequencing targeting functional genes (Karr et al., 2005; Kong et al., 2012; Dolhi et al., 2015), taxonomic marker genes (e.g., rRNA genes) (Glatz et al., 2006; Mikucki and Priscu, 2007; Bielewicz et al., 2011; Tang et al., 2013) and 454 pyrosequencing (Vick-Majors et al., 2013; Bowman et al., 2016). Research by Vick-Majors et al. (2013) and Glatz et al. (2006) uncovered a portion of this diversity but these studies focused on one or two lakes and at limited depths. Consequently, finer-scale taxa composition remains poorly understood.

Four of the ice-covered lakes included in our survey are linearly arranged in Taylor Valley (TV), with the two lobes of Lake Bonney connected by sill at their southwest ends and Lake Fryxell located in the northeastern end of TV (Green and Lyons, 2009). Canada Glacier is directly connected and feeds melt water to both Lake Hoare and Lake Fryxell (Clocksin et al., 2007). Although all of the lakes are located within the same valley, they differ in their biogeochemical characteristics and evaporitic histories (Green and Lyons, 2009). On the other hand, freshwater Lake Miers, located in Miers Valley, exhibits numerous biogeochemical similarities with the lakes in TV (Bell, 1967). Nutrients and microbes are dispersed primarily via aeolian transport or glacial melt water from lake to lake across the MDVs (Sabacka et al., 2012), and thus it is possible that biogeographically dispersed 'generalists' are shared across lakes, whereas each lake also harbors unique microbial populations owing to confined niches under strong selection pressure.

The aim of this study was to compare the diversity and structure of bacterial communities among these icecovered MDV lakes to test the hypothesis that many uncharted branches in the bacterial tree of life may yet be found under the unique environmental conditions within the lakes of the Antarctic. Specific questions addressed in our study include: how do bacterial communities differ by lake, depth and size-fractions? Are any taxa limited to certain lakes or regions of the lakes? How do bacterial communities vary over the summer growth season, that is, over 2 months of continuous sunlight marked by increased biomass and productivity? Is the distribution of bacteria related to contemporary geochemistry within and between lakes?

To address these questions, we investigated the vertical bacterial community structure of five ice-covered lakes in the MDVs by $16 \mathrm{~S}$ rRNA gene-based pyrosequencing, along with patterns of community composition and distribution relating to in situ conditions.

\section{Experimental procedures}

\section{Site description and sample collection}

The five lakes included in our study lie in the Taylor (Fryxell, FRX; Hoare, HOR; East Lobe Bonney, ELB; and West Lobe Bonney, WLB) and Miers (Miers, MIE) valleys, and have been the focus of more than 20 years of research by an NSF-funded McMurdo Long-Term Ecological Research (MCM LTER) project (http://mcmlter.org; Fig. 1). The FRX, HOR, ELB and WLB lakes are hydraulically terminal (i.e., lacking outflows), whereas MIE has a seasonal outflow to the sea during periods of high water levels. The lakes receive continuous sunlight during the summer but no sunlight between mid-April and late September (Bowman et al., 2016; Morgan-Kiss et al., 2016). The geochemistries differ among these lakes; for one, they can be divided into three categories of salinity, with FRX being brackish, ELB and WLB hypersaline and MIE and HOR freshwater (Green and Lyons, 2009). The deeper waters of FRX are strongly anaerobic and this is the only lake to feature high levels of sulfide, whereas dissolved organic carbon (DOC) concentrations generally increase with depth in all five lakes. Lakes ELB and WLB are strongly phosphorous $(\mathrm{P})$-deficient, whereas the other three lakes are both nitrogen $(\mathrm{N})$ and $\mathrm{P}$ deficient (Priscu, 1995; Dore and Priscu, 2001). Detailed profiles of inorganic nutrients and dissolved organic carbon can be found in Priscu (1995, 1997). In regard to $\mathrm{N}$ chemistry, $\mathrm{NO}_{3}^{-}$is depleted in the surface layers, whereas concentrations of $\mathrm{NH}_{4}^{+}$are high in the anoxic deeper layers of lakes FRX and WLB.

A total of 40 samples were collected from depths representing the geochemically distinct water layers in each lake for pyrosequencing. Biogeochemical measurements were conducted in November and December 2012, with the exception of HOR, for which November measurements were unavailable owing to logistical constraints. Previous research has shown that most bacteria can be divided into particle-associated bacteria $(>3.0 \mu \mathrm{m})$, and small $(0.2-1.0 \mu \mathrm{m})$ and large $(1.0-3.0$ $\mu \mathrm{m})$ free-living bacteria (Simon, 1985). To differentiate between particle-associated $(>3.0 \mu \mathrm{m})$ and free-living $(0.2$ to $3.0 \mu \mathrm{m})$ bacterial assemblages, we size-fractionated freshly collected water samples into $>3.0 \mu \mathrm{m}$ and 3.0-0.2 $\mu \mathrm{m}$ size classes by sequential filtration through $3.0 \mu \mathrm{m}$ (ADVANTEC, Japan) and $0.2 \mu \mathrm{m}$ (Millipore, Germany) membrane filters. We set the $>3.0 \mu \mathrm{m}$ sized filter as the upper limit of pore size, given that microbial cells in these lakes are known to be dominated by picoplankton (Kong et al., 2014). The filtered samples were stored at $-20^{\circ} \mathrm{C}$ during shipment to Korea, where they were stored at $-80^{\circ} \mathrm{C}$ until used in the analyses.

\section{Chemical analyses and primary production measurements}

Samples were analyzed according to the procedures outlined in the MCM LTER manual (http://www.mcmlter.org/data/mcmIter-data-file-format-protocols-database-submission), briefly summarised below. Temperature and conductivity were measured with an SBE 25 Sealogger CTD. Dissolved oxygen (DO) was measured using the azide modification of the miniWinkler titration, and underwater photosynthetically active radiation (UwPAR) was measured using a LI-COR LI-193SA spherical quantum sensor (LI-COR Biosciences) at local noon. 

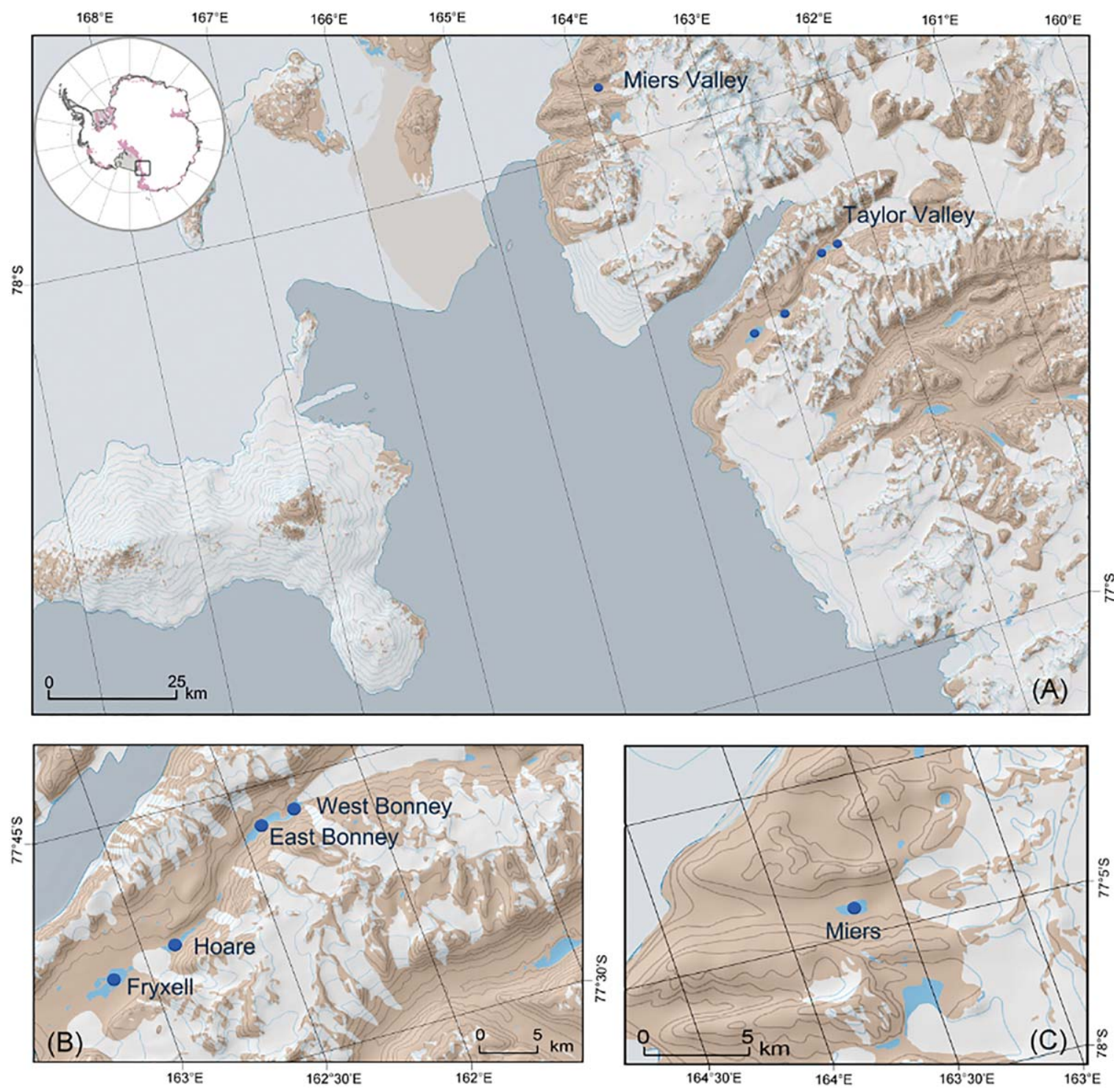

Fig. 1. Map of sampling locations in (A) McMurdo Dry Valleys of Antarctica. (B) FRX, HOR, ELB and WLB are located in Taylor Valley, and (C) MIE in Miers Valley. [Color figure can be viewed at wileyonlinelibrary.com]

Macronutrients $\left(\mathrm{NH}_{4}^{+}, \mathrm{NO}_{3}^{-}, \mathrm{NO}_{2}^{-}\right)$were analysed as described by Priscu (1995). Dissolved organic carbon (DOC) was determined using a Shimadzu TOC-V series total organic carbon (C) analyzer. All DOC samples were filtered through precombusted and acid-leached $25 \mathrm{~mm}$ GF/F filters and acidified to a $\mathrm{pH}$ of 2 with $6 \mathrm{~N} \mathrm{HCl}$ to eliminate inorganic $\mathrm{C}$. Phytoplankton primary production (PPR) was measured by incubating duplicate light and a single dark sample in situ for $24 \mathrm{~h}$ with ${ }^{14} \mathrm{C}$-labeled bicarbonate. Heterotrophic bacterial productivity (BP) was measured using $\left[{ }^{3} \mathrm{H}\right]$ methyl-thymidine incorporation into DNA.

\section{Pyrosequencing and data analyses}

Genomic DNA was extracted from half of each filter membrane (after $\sim 1$ I had passed through) using a FastDNA $\AA$ SPIN kit (MP Biomedicals, Illkirch, France) following the manufacturer's instructions. Extracted DNA from 80 filter samples were amplified, with the $\mathrm{V} 1-\mathrm{V} 3$ region of the $16 \mathrm{~S}$ rRNA gene targeted using barcoded fusion primers (27F: $5^{\prime}-\mathrm{X}-\mathrm{AC}$ AGAGTTTGATCMTGGCTCAG-3' and 519R: 5'-X-ACGWATTACCGCGGCKGCTG-3', where ' $X$ ' denotes 8 bp errorcorrected barcodes and 'AC' is a 2 bp linker sequence) (Lane, 1991). A total volume of $50 \mu \mathrm{l}$ was used in PCR, consisting of $2 \mu \mathrm{l}$ of DNA, $0.5 \mu \mathrm{l}$ of each primer (10 pmol), $1 \mu \mathrm{l}$ of Taq polymerase (2.5 U/ $\mu \mathrm{l}$; GeneAll, Korea), $4 \mu \mathrm{l}$ of dNTP mix $(2.5 \mathrm{mM}$ each) and $5 \mu$ of $10 X$ buffer containing the enzyme, under the following conditions: an initial denaturation step at $94^{\circ} \mathrm{C}$ for 5 min followed by 25 cycles of $94^{\circ} \mathrm{C}$ for $1 \mathrm{~min}, 50^{\circ} \mathrm{C}$ for $1 \mathrm{~min}$ and $72^{\circ} \mathrm{C}$ for $1.5 \mathrm{~min}$. PCR products could not be recovered from two $0.2 \mu \mathrm{m}$-filtered samples of $30 \mathrm{~m}$ (November) and $30 \mathrm{~m}$ (December) in samples from ELB. The 454 adapter sequence was incorporated into the purified PCR product. 
Pyrosequencing was performed by Macrogen (Seoul, Korea) using a 454 GS FLX+ Sequencing System (Roche, CT, USA). Barcode, linker and primer sequences were trimmed, with low-quality sequences removed from the dataset using PyroTrimmer (Oh et al., 2012). The quality-filtered sequences were further processed following the 454 SOP using mothur (Schloss et al., 2009). The resultant partial 16S rRNA gene sequences were clustered into operational taxonomic units (OTUs) based on a cutoff of $97 \%$ sequence similarity. Singleton OTUs were excluded from subsequent analyses to reduce artifacts of PCR or sequencing errors. Taxonomic classification was performed using the Naïve Bayesian Classifier implemented in mothur against the EzTaxon-e database (http://eztaxon-e.ezbiocloud.net) (Kim et al., 2012). All 16S rRNA gene sequences that originated from archaea, chloroplast and mitochondria were removed. Raw reads were submitted to the NCBI SRA database (accession number PRJNA276598).

\section{Quantitative PCR}

To estimate bacterial rRNA gene abundance, we performed quantitative PCR using a CFX96 qPCR System (Bio-Rad, Hercules, CA, USA) with SYBR Green as the fluorescent reporter (Bio-Rad, USA) by quantifying bacterial 16S rRNA gene copies. Partial 16S rRNA genes were amplified using the bacteria-specific primer set, 341f (5'-CCTACGGGAGG CAGCAG-3') and 797r (5'-GGACTACCAGGGTCTAATCCTG TT-3') (Lane, 1991; Nadkarni et al., 2002). Amplification followed a three-step PCR consisting of 44 cycles with denaturation at $94^{\circ} \mathrm{C}$ for $25 \mathrm{~s}$, primer annealing at $64.5^{\circ} \mathrm{C}$ for $25 \mathrm{~s}$ and extension at $72^{\circ} \mathrm{C}$ for $25 \mathrm{~s}$. Two independent real-time PCR assays were performed on each sample. The standard curves were created using a tenfold dilution series of plasmids containing the bacterial 16S rRNA gene from environmental samples; the $R^{2}$ for standard curves was 0.99 . Tenfold dilution series ranging from $10^{-5}$ to $10^{-9}$ were run in triplicate for each sample, as were negative controls containing no DNA template. It should be noted that quantification of the 16S rRNA gene copy number does not provide accurate estimates for bacterial abundance because the rRNA gene copy number varies between bacterial taxa and primers used for qPCR do not cover the entire bacterial population. However, qPCR assays have frequently been used in microbial ecology studies due to their reproducibility (Fierer et al., 2005; Takahashi et al., 2014).

\section{$16 S$ rRNA gene cloning, sequencing and phylogenetic analysis}

To retrieve more complete phylogenetic information about unknown WM88 lineages found in FRX, DNA extracted from a $3.0 \mu \mathrm{m}$-filtered FRX sample collected at a depth of $15 \mathrm{~m}$ was used for clone library construction targeting the full-length bacterial 16S rRNA gene sequence. PCR was performed using the primer set $27 \mathrm{f}$ and $1492 \mathrm{r}$ with the same reaction condition as described above (Lane, 1991). The PCR product was cloned into the vector, using a TOPO TA cloning kit (Invitrogen, CA, USA), with 50 randomly selected clones sequenced using M13F/M13R primers with $\mathrm{ABI} 3700$ capillary sequencer
(Applied Biosystems, CA, USA). Putative chimeric sequences were deleted using chimera.uchime implemented in mothur based on the chimera-free SILVA gold database (v.123).

Representative 16S rRNA gene sequences for each bacterial phyla were downloaded from EzTaxon-e database (42 phyla and 911 sequences) and aligned against a high-quality reference alignment obtained from EzTaxon-e using SINA v1.2.11 (Pruesse et al., 2012). The alignment quality was manually checked based on the secondary structure of $16 \mathrm{~S}$ rRNA using jPhydit (Jeon et al., 2005). A phylogenetic tree was constructed by maximum likelihood (ML) analysis with the GTR $+\Gamma$ model of nucleotide substitution in RAxML v8.2.9 (Stamatakis, 2014). The reliability of the tree topology was assessed by generating 100 bootstrap replicates using the $-f$ a option, which enables a rapid bootstrap analysis and search for the best-scoring $\mathrm{ML}$ tree in RAxML. Bootstrap convergence was tested using the -I autoMRE option, with convergence achieved at 300 replicates. We then performed a new rapid bootstrap analysis with 1000 replicates to obtain stable support values. The $16 \mathrm{~S}$ rRNA gene sequences obtained in this study were deposited in GenBank (accession numbers KP862888 to KP862894).

\section{Statistical analyses}

We compared the richness and diversity of the bacterial communities among samples by minimising the effects of different library size and sequencing depth; thus, diversity comparisons between samples were conducted after library size or sample coverage were equalised among samples. To equalise library size among the samples, the resultant high-quality reads were standardized to the smallest library size $(n=562)$ by randomly subsampling reads 100 times per sample. The level of diversity among samples was also compared at equal sample coverage (0.943) using the 'estimateD' function in the iNEXT $\mathrm{R}$ package (Hsieh et al., 2016). Diversity indices were generated based on OTUs of at least $97 \%$ sequence similarity of the 16S rRNA gene, using mothur. Bray-Curtis dissimilarities were calculated using a Hellinger-transformed OTU matrix and non-metric multidimensional scaling (NMDS) analysis was performed based on the dissimilarity matrix using PRIMER 6+ (Clarke and Gorley, 2006). To test if bacterial community compositions significantly differed by lakes and depths, a permutational multivariate analysis of variance (PERMANOVA) (Anderson, 2001) was performed with 999 permutations, using the 'adonis' function in the vegan $\mathrm{R}$ package (Oksanen et al., 2015).

Distance-based linear models (DISTLM) were used to examine the relationships between environmental variables and bacterial community structure by partitioning variation in community structure according to a multiple regression model (Legendre and Anderson, 1999). Prior to DISTLM, the distribution of each environmental variable was plotted, with normalising transformations performed on skewed variables according to the 'Draftsman plot' result in PRIMER 6+. Month (November and December) was transformed into a dummy variable; depth, UwPAR, AmbPAR, Chl-a and PPR were square-root transformed; and $\mathrm{NH}_{4}^{+}, \mathrm{NO}_{3}^{-}, \mathrm{NO}_{2}^{-}$, DOC, DIC, $\mathrm{BP}, \mathrm{SO}_{4}^{2-}$, conductivity, $\mathrm{Na}, \mathrm{K}, \mathrm{Mg}, \mathrm{Ca}$ and $\mathrm{Cl}$ were logtransformed. The remaining variables were left untransformed. Highly correlated variables (Pearson's $|r|>0.90$ ) in each lake 


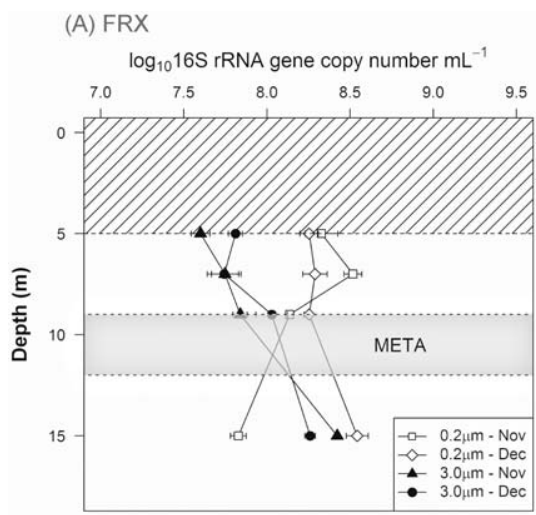

(B) MIE

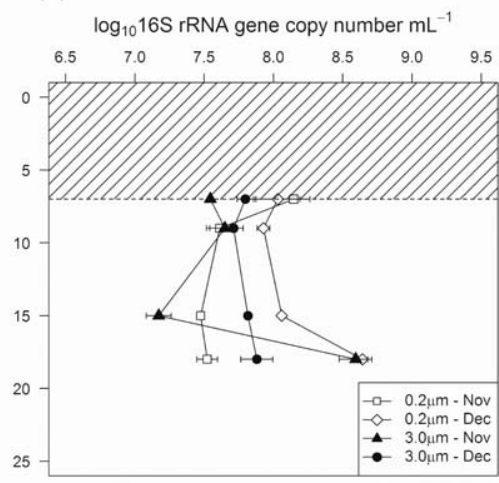

(C) ELB
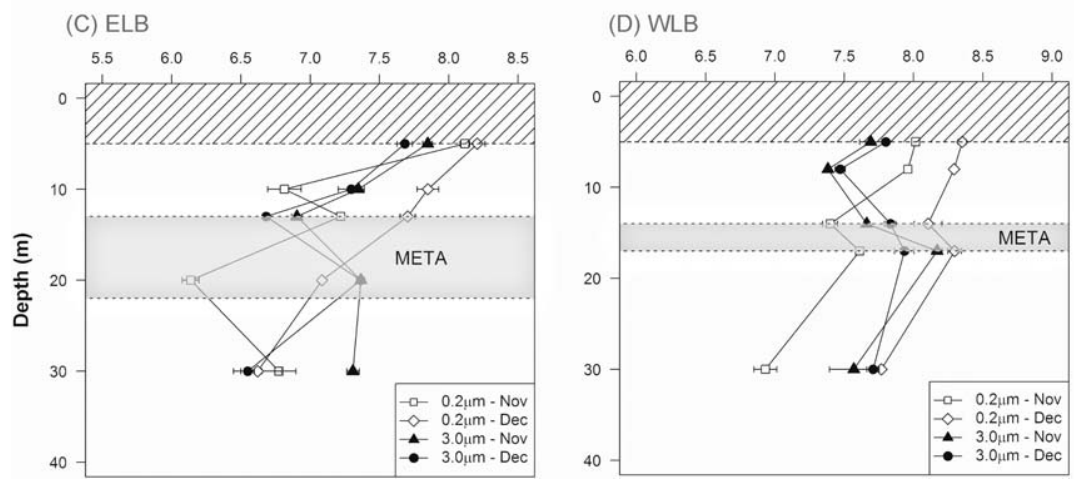

(E) HOR

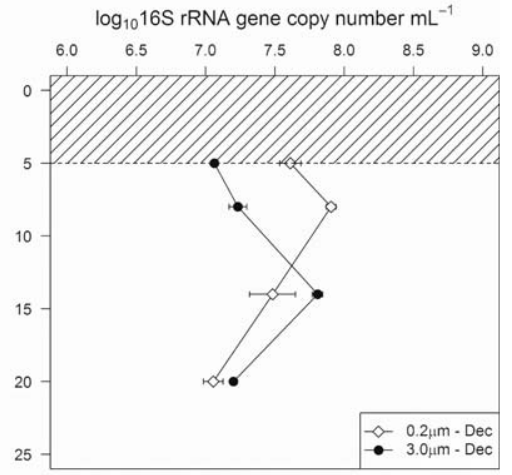

Fig. 2. Depth profiles of bacterial $16 \mathrm{~S}$ rRNA gene copy numbers in (A) FRX, (B) MIE, (C) ELB, (D) WLB and (E) HOR. Regions shaded with diagonal lines represent the permanent ice cover of each lake. Grey-shaded area indicate metalimnion (or chemocline) that isolate the deep saline waters from the fresh surface waters.

were excluded by testing multicollinearity between predictor variables. Forward selection of transformed environmental variables was performed to determine how much of the variation in community structure was explained by an individual variable alone or in combination with other variables, and the best model was selected based on adjusted $R^{2}$ values of each model. The combination of environmental variables that best explained community variation was selected and graphically represented as distance-based redundancy analysis (db-RDA). Basic statistical analyses and plotting were performed in $\mathrm{R}$ version 3.0.2 (R Core Team, 2013).

\section{Results}

\section{Biogeochemical characteristics of the MDV lakes}

Biogeophysical characteristics of the lakes determined during the austral summer are presented in Supporting Information Tables S1 and S2. These data show the strong vertical gradients in ionic strength within each lake and the differences among lakes. Oxygen levels above the chemocline are all above air saturation, whereas deeper waters are typically suboxic. Only the deep waters of FRX were highly anoxic and contained high levels of hydrogen sulfide $(\sim 1.8 \mathrm{mM})$. All of the lakes had deep Chl-a layers, and corresponding high levels of primary production were detected just above the chemoclines. Bacterial productivity often peaked with Chl-a and phytoplankton productivity maxima, and DOC and inorganic $\mathrm{N}$ and $\mathrm{P}$ were always higher in the deep saline waters, reaching $\mathrm{mM}$ levels in several of the lakes.

Distribution and relative abundance of bacterial biomass

Bacterial 16S rRNA gene abundance (which can be used to represent biomass when the assumption that all organisms have the same number of copies of the gene is adopted) during November and December was estimated by $\mathrm{qPCR}$ in the two size fractions $(3.0 \mu \mathrm{m}$ and $0.2 \mu \mathrm{m})$ (Fig. 2). Overall, vertical trends in bacterial biomass differed by lake, size-fraction and month. In FRX, bacterial biomass increased with depth in all samples except for the $0.2 \mu \mathrm{m}$-November samples, which peaked at $7 \mathrm{~m}$ followed by a decline in biomass, to $15 \mathrm{~m}$. In MIE, bacterial abundance was relatively uniform throughout the water column, with the exception of peaks in the $0.2 \mu \mathrm{m}$-December and $3.0 \mu \mathrm{m}$-November fractions at a depth of $18 \mathrm{~m}$ that were more than five times above the average abundance. In ELB, the greatest bacterial abundance was found immediately below the ice cover $(5 \mathrm{~m})$; abundance declined with increasing depth, to $20 \mathrm{~m}$, but remained relatively constant between 20 and $30 \mathrm{~m}$ depths. In WLB, bacterial 
abundance generally decreased with depth, although an increase associated with the chemocline $(10 \mathrm{~m})$ was observed in all size fractions. In HOR, bacterial abundance increased from the surface to depths of $8 \mathrm{~m}$ in the $0.2 \mu \mathrm{m}$ fraction and $15 \mathrm{~m}$ in the $3 \mu \mathrm{m}$ fraction, then declined below these depths. The depth of maximal abundance differed between the two size fractions in HOR, with abundance peaking at depths of $7 \mathrm{~m}$ in the $0.2 \mu \mathrm{m}$-December samples and $15 \mathrm{~m}$ in the $3.0 \mu \mathrm{m}$-December samples.

\section{Distribution of bacterial phyla among lakes and depths}

A total of 185755 (average of 2468 reads per sample, with a range of 562 to 6775 ) high-quality sequences were obtained from 78 samples. Good's coverage averaged 0.95 among the samples (range of 0.87-0.99). Sequences were clustered into 2085 OTUs affiliated with 42 bacterial phyla. Variations were observed in bacterial diversity among lakes and depths. When the level of diversity was compared across samples at the equal library size and sample coverage, bacterial diversity was overall higher in the $3.0 \mu \mathrm{m}$ filtered samples than in the $0.2 \mu \mathrm{m}$-filtered samples (pairedsample Wilcoxon signed-rank test, $P<0.01$ ), a pattern that was also observed in the rarefaction and extrapolation curves (Supporting Information Fig. S1). In contrast, bacterial diversity was much higher in the $0.2 \mu \mathrm{m}$ size fractions than in the $3.0 \mu \mathrm{m}$ size fractions in the deepest layer of FRX (15 m; $P<0.01$ ) (Supporting Information Table S3 and Fig. S1). Among the $0.2 \mu \mathrm{m}$-filtered samples, the highest levels of bacterial diversity occurred in the deepest layers of lakes FRX $(15 \mathrm{~m})$ and WLB $(30 \mathrm{~m})$ compared to diversity in the upper layers, with no apparent trends detected in the other lakes (Supporting Information Table S3).

The distribution of major phyla differed by lake, depth and size fraction (Fig. 3 and Supporting Information Table S4). Bacteroidetes and Actinobacteria were abundant across all depths and lakes, with Proteobacteria the next most abundant phylum, most of which consisted of Betaproteobacteria. The two hypersaline lakes, ELB and WLB, had relatively similar phyla compositions, whereas the brackish and freshwater lakes (FRX, MIE and HOR) had more bacterial phyla in common. Phyla distribution also varied considerably with size fraction: Actinobacteria were generally more abundant in the $0.2 \mu \mathrm{m}$ fractions than in the $3.0 \mu \mathrm{m}$ fractions at equivalent depths, whereas Planctomycetes, Verrucomicrobia and Cyanobacteria were more abundant in the $3.0 \mu \mathrm{m}$ fractions. Below the chemocline in FRX, candidate division WM88 (also classified as Hyd2412 (Kirkegaard et al., 2016) in SILVA taxonomy) was more abundant in the $3.0 \mu \mathrm{m}$ fractions. Candidate division JS1 (also known as OP9 or 'Atribacteria') was more common in the $0.2 \mu \mathrm{m}$ fractions than in the $3.0 \mu \mathrm{m}$ fractions in the bottom layer of FRX, and relatively higher numbers of

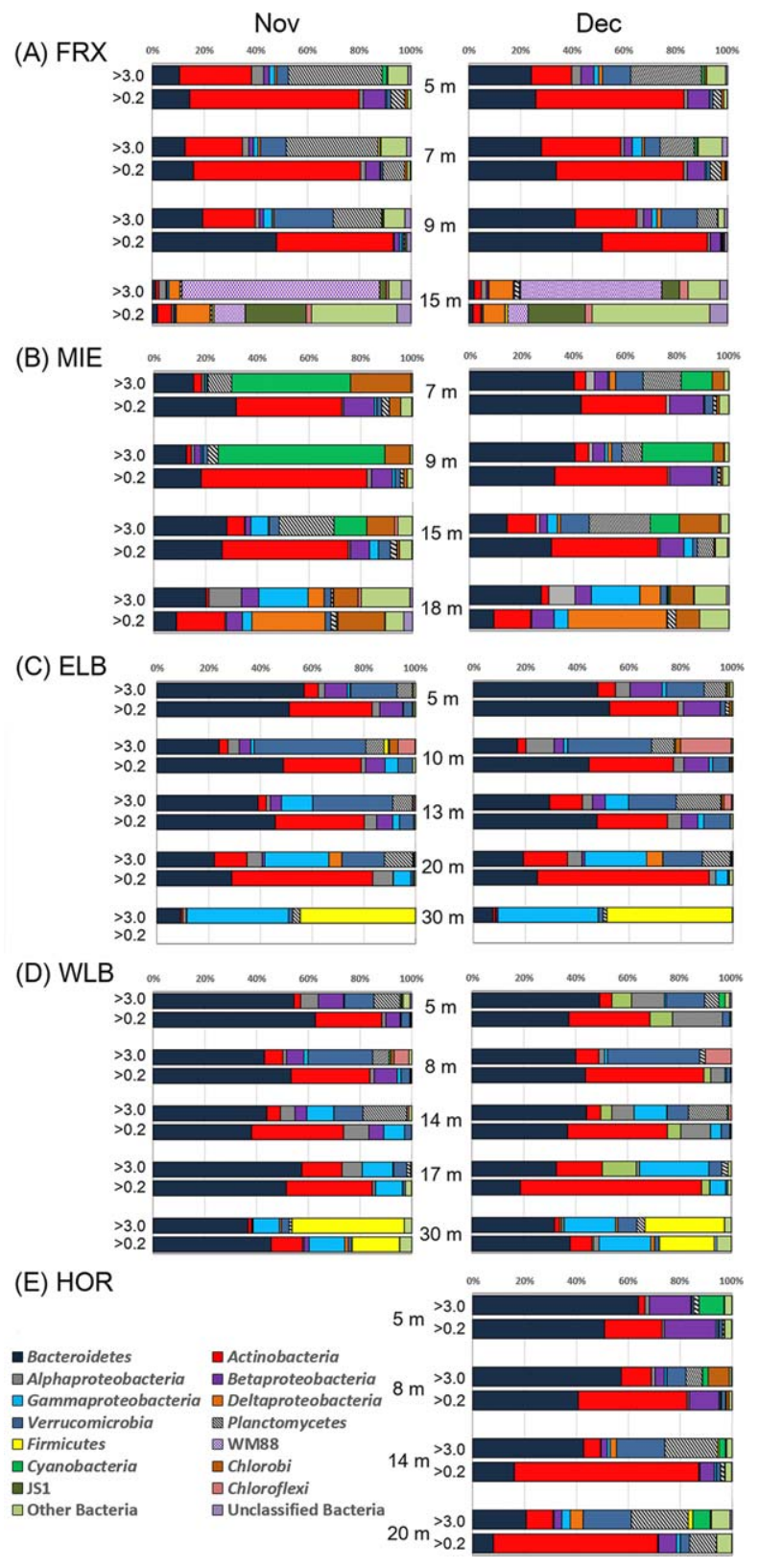

Fig. 3. Bacterial phyla distribution differing by lake, depth and size fraction: (A) FRX, (B) MIE, (C) ELB, (D) WLB and (E) HOR. Other bacteria denote the group of relatively rare phyla with a relative abundance $<0.7 \%$ in total reads among five lakes (See Supporting Information for detail in Table S4). Upper and lower bars denote the $>3.0 \mu \mathrm{m}$ and the 0.2 to $3.0 \mu \mathrm{m}$ fractions, respectively. The $0.2 \mu \mathrm{m}$ fraction collected cells that passed through the $3.0 \mu \mathrm{m}$ membrane filters.

Deltaproteobacteria were observed in the $0.2 \mu \mathrm{m}$ fractions in the lower layers of MIE.

Each lake had distinctive patterns of phyla by depth, especially at the lowest depths. In FRX, Betaproteobacteria, Planctomycetes and candidate division WS5 decreased with depth, whereas Bacteroidetes became more abundant from the surface of the lake to $9 \mathrm{~m}$. The 
$0.2 \mu \mathrm{m}$ fraction of the deepest layer $(15 \mathrm{~m})$ was dominated by various bacterial phyla, including Proteobacteria (mostly Deltaproteobacteria, $14.9 \%$ in November and $9.3 \%$ in December), Tenericutes (12.9\% in November and 13.1\% in December) and Actinobacteria (5.5\% in November and $3.0 \%$ in December); moreover, candidate divisions such as JS1 (23.5\% in November and 22.1\% in December), WM88 (12.1\% in November and $7.9 \%$ in December), SAR406 (5.4\% in November and $11.4 \%$ in December), OD1 (5.0\% in November and $8.5 \%$ in December) and Candidatus Cloacamonas (4.3\% in November and $3.1 \%$ in December) were also highly abundant at this depth. Notably, candidate division WM88 constituted more than half $(76.4 \%$ in November and $54.6 \%$ in December) of the $3.0 \mu \mathrm{m}$ fraction sequences at $15 \mathrm{~m}$ depth. In MIE, there was no apparent shift in phyla abundance down to $15 \mathrm{~m}$ in the $0.2 \mu \mathrm{m}$ fraction, with over $80 \%$ of the total assemblages dominated by Bacteroidetes, Actinobacteria and Betaproteobacteria. As expected, Cyanobacteria, most of which are filamentous, accounted for a large proportion of the $3.0 \mu \mathrm{m}$ fractions at depths of 7-15 m (relative abundance of $12.7-64.5 \%$ in November and $0.7-27.5 \%$ in December), whereas they were virtually absent in the $0.2 \mu \mathrm{m}$ fractions at the same depths. The proportions of Bacteroidetes and Actinobacteria were relatively low in the bottom layer of MIE (18 m), whereas Deltaproteobacteria $28.3 \%$ in November and $38.1 \%$ in December) and Chlorobi $(18.2 \%$ in November and $9.1 \%$ in December) accounted for almost half of the total bacteria found in this layer in the $0.2 \mu \mathrm{m}$ fractions. In addition, both Alphaproteobacteria and Gammaproteobacteria were markedly more abundant in the $3.0 \mu \mathrm{m}$ fractions. In lakes ELB and WLB, Bacteroidetes and Actinobacteria were prominent at almost all depths, although distribution of bacterial phyla at $30 \mathrm{~m}$ was distinctive in both ELB and WLB; Gammaproteobacteria $39.3 \%$ in November and $38.7 \%$ in December) and Firmicutes (44.6\% in November and $48.3 \%$ in December) were common in the $3.0 \mu \mathrm{m}$ fractions at this depth in ELB, and Firmicutes was also abundant at $30 \mathrm{~m}$ in WLB $(43.4 \%$ in November and $30.7 \%$ in December), but Bacteroidetes abundance at $30 \mathrm{~m}$ was dramatically lower in ELB $(9.2 \%$ in November and $7.5 \%$ in December) than in WLB $(36.7 \%$ in November and $31.8 \%$ in December). Bacteroidetes and Actinobacteria were also predominant at all depths in HOR, but Bacteroidetes steadily declined in abundance down to $20 \mathrm{~m}$ and Actinobacteria were more abundant in the two bottom layers (14 $\mathrm{m}$ and $20 \mathrm{~m}$ ) than in the upper layers.

\section{Bacterial differentiation between lakes and their relationship with physicochemical properties}

There was a significant difference in bacterial community composition among the lakes in both size fractions (PERMANOVA, pseudo- $F_{4,37}=3.15$ and $P<0.001$ for $0.2 \mu \mathrm{m}$; pseudo- $F_{4,39}=3.38$ and $P<0.001$ for $\left.3.0 \mu \mathrm{m}\right)$. Lakes FRX and MIE had the most distinctive communities (PERMANOVA pairwise test, all $P<0.01$ except for $P=0.263$ and $P=0.087$ with $\mathrm{HOR}$, respectively), whereas community compositions in lakes WLB and ELB were more similar to each other than to the other lakes $(P=0.371)$. Depth was also a determining factor in the differentiation of the bacterial communities $(P<0.001)$. The NMDS analysis revealed that the bottom layers had the most distinctive assemblages in all lakes, whereas communities tended to converge in the surface layers when hierarchical clustering was overlaid onto the ordination space (Fig. 4). Bacterial communities also varied by size fraction and sampling time, although this variability was much lower than that attributable to the factors of lake and depth. Sampling time did not significantly contribute to the community composition variation when modeled alone or together with lake and depth variables (all $P>0.05$ ).

To determine which combination of environmental variables best explains the community variation among these lakes, the most parsimonious model was selected using DISTLM and the result was graphically displayed using db-RDA. Best-predictor variables varied when modeled for each individual lake (Supporting Information Fig. S2); $\mathrm{SO}_{4}^{2-}$ was one of the best predictor variables for all lakes, and the single best-predictor for lakes MIE and WLB. The best predictor variables for FRX, ELB and $\mathrm{HOR}$ were $\mathrm{BP}, \mathrm{NO}_{3}^{-}$and $\mathrm{DOC}$, respectively. Predictor variables differed by lake in multi-factor models; $\mathrm{BP}, \mathrm{Chl}-$ a, $\mathrm{SO}_{4}^{2-}$ and PPR were the major predictor variables for FRX, whereas variation in the MIE community was largely explained by depth, $\mathrm{Chl}-\mathrm{a}$ and $\mathrm{SO}_{4}^{2-}$. For ELB, $\mathrm{NO}_{2}^{-}$ was strongly associated with the bottom layer $(30 \mathrm{~m}$ depth), whereas deeper strata (17 m and $30 \mathrm{~m}$ ) of WLB were positively correlated with $\mathrm{NH}_{4}^{+}$. Community variation in $\mathrm{HOR}$ was most strongly associated with $\mathrm{SO}_{4}^{2-}$ and $\mathrm{pH}$.

\section{Shared OTUs between lakes}

Given the striking differences in bacterial community compositions among lakes and by depth, we next examined whether any of the identified taxa were limited to a specific region within a lake, which would indicate decreased niche width relative to other bacterial taxa. Only 3\% (62 OTUs) of the 2085 OTUs were shared among the lakes when all data were combined (Fig. 5), with FRX harboring the largest proportion of unique OTUs (24.6\%) and WLB the lowest $(8.6 \%)$. Certain bacterial lineages occurred exclusively at particular depths within lakes (Supporting Information Table S5); for instance, OTUs belonging to Tenericutes and Deltaproteobacteria, as well as several candidate divisions such as WM88, JS1 and SAR406, were almost exclusively found at a depth of $15 \mathrm{~m}$ in FRX. 

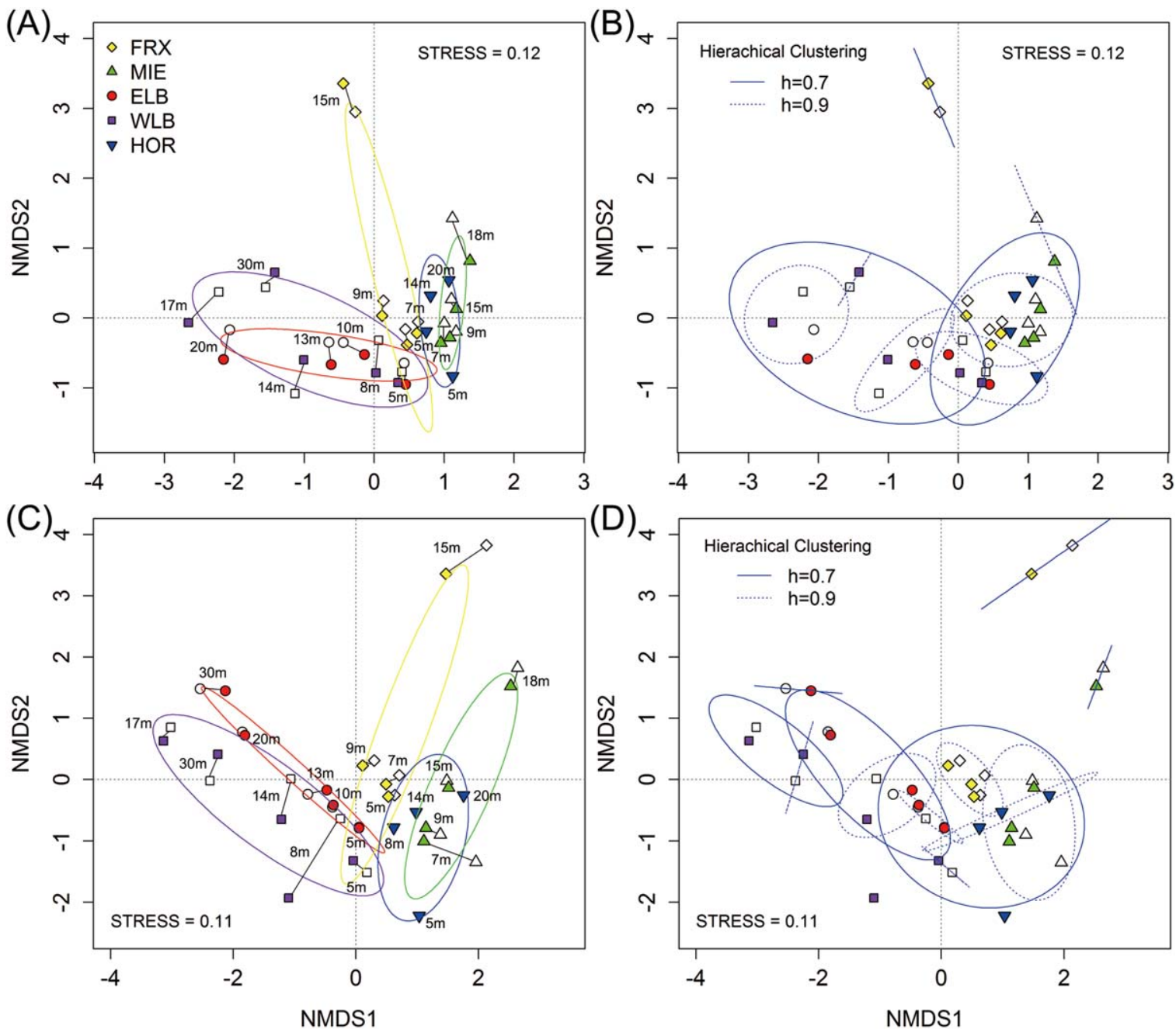

Fig. 4. NMDS plot of OTU-level bacterial community composition: Panels $(A)$ and $(B)$ represent the $0.2-3.0 \mu \mathrm{m}$ size fraction; Panels (C) and (D) represent the $>3.0 \mu \mathrm{m}$ size fraction. OTU abundance matrices were used to calculate Bray-Curtis dissimilarities between samples. Hierachical clustering results were overlaid onto the ordination space in (B) and (D). November (open symbols) and December (closed symbols) samples at the same depth are linked by solid lines and samples from the same lake were grouped by ellipses with different colours in $(\mathrm{A})$ and $(\mathrm{C})$ to help visualise groupings between different lakes. [Color figure can be viewed at wileyonlinelibrary.com]

Phylogenetic analysis based on the full-length 16S rRNA gene sequences indicated that these lineages are novel WM88 clades (Fryxell_set2 and Fryxell_13) that are distinct from other known relatives. The JS1 clone sequence (Fryxell_39) was placed among lineages originating from sub-seafloor sediments (Fig. 6 and Supporting Information Table S6). Sequences affiliated with the genus Ignavibacterium (phylum Chlorobi) were only found at a depth of $18 \mathrm{~m}$ in MIE (relative abundance of 7.9-17.9\%). Virgibacillus was found in the $3.0 \mu \mathrm{m}$ fraction at a depth of $30 \mathrm{~m}$ in ELB (39.0\% in November and $41.4 \%$ in December) and an unknown genus of Clostridiales (EU245980_g) was collected from the $30 \mathrm{~m}$ layer of WLB (11.0-22.8\%). Mariprofundus-related OTUs of Zetaproteobacteria were present only at depths of $17 \mathrm{~m}$ and $30 \mathrm{~m}$ in WLB (0.7$1.6 \%$ and $3.1-3.7 \%$, respectively).

\section{Discussion}

To the best of our knowledge, this is the first comprehensive comparison of bacterial communities inhabiting the ice-covered lakes in McMurdo Dry Valleys, Antarctica, by high-throughput sequencing. Previous long-term research has largely focused on identifying the physicochemical characteristics and biological productivity of these unique lakes (Smith et al., 1993; Green and Lyons, 2009), and studies that have examined community compositions have either focused on eukaryotes (Kong et al., 2014; Morgan-Kiss et al., 2016) or involved limited samples and sequencing effort (Gordon et al., 2000; VickMajors et al., 2013). The use of high-throughput sequencing techniques to investigate the relationships between physicochemical properties and bacterial 


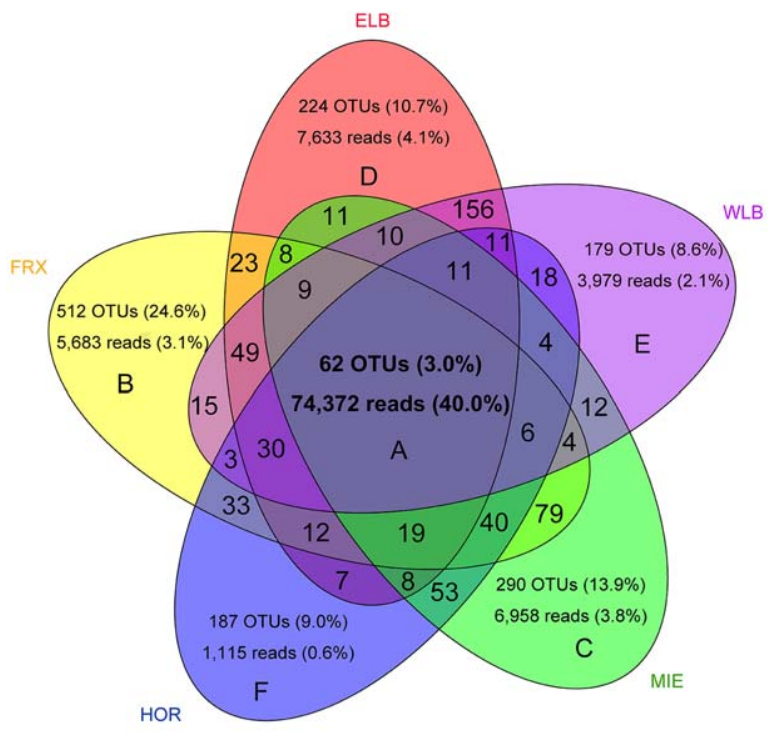

Fig. 5. Venn diagram showing the overlap in bacterial OTUs among the five lakes. Numbers of OTUs represents all data combined (all depths, sampling times and size fractions in the lake). OTU details of A-F regions are shown in Supporting information Table S5. [Color figure can be viewed at wileyonlinelibrary.com]

community composition has provided novel insights into the niche specialization of bacterial lineages among depths and between lakes.

Although not uniformly true, bacterial diversity in these lakes was often found to be higher among the $>3.0 \mu \mathrm{m}$ size fractions than among the $0.2 \mu \mathrm{m}$ fractions across all samples. The reason for the differences in richness and diversity between the two fractions remains elusive, but a possible explanation is that particle-associated bacteria may be more efficient at obtaining nutrients and thus better at surviving in harsh aquatic environments than are freeliving bacteria (Berman, 1975). It is also possible that diverse bacterial lineages associated with microbial eukaryotes contribute to the higher bacterial richness in the larger size fractions (Li et al., 2016).

Contrary to the pattern for bacterial diversity, relatively lower abundance in 16S rRNA gene copy numbers were observed in the $3.0 \mu \mathrm{m}$ fractions at upper layers, which may reflect the nature of sinking particles through the depths. However, vertical trends in 16S rRNA gene copies varied markedly by lake, depth and size fractions, which may be attributed to variability in resource availability driven by the environmental conditions within each water column.

Bacteroidetes and Actinobacteria dominated the bacterial communities in all of the lakes, a finding consistent with the results of previous analyses of lakes Fryxell and Bonney (Glatz et al., 2006; Vick-Majors et al., 2013). Bacterial genera within these two phyla are similar to those found in other aquatic systems, and include freshwater and seawater lineages (Glöckner et al., 1999; Newton et al., 2011). Betaproteobacteria abundance was also consistently high at deeper depths in all lakes. The half of assigned Betaproteobacteria (43.3\% of total Betaproteobacteria) affiliated with genus Polaromonas. Members of Polaromonas, psychrophilic representatives of gram-negative bacteria, display striking cold-adaptive characteristics (Feller and Gerday, 2003) and are ubiquitous in cold and highelevation environments, such as glacial ice and periglacial soils, across the globe (Darcy et al., 2011) and in Antarctic lakes (Michaud et al., 2012). Gammaproteobacteria were dominant only in deeper layers of East and West Lobe Bonney, which may be due to the hypersaline environments of both lakes. Predominance of Marinobacter and Halomonas at depths of $30 \mathrm{~m}$ in these two lakes
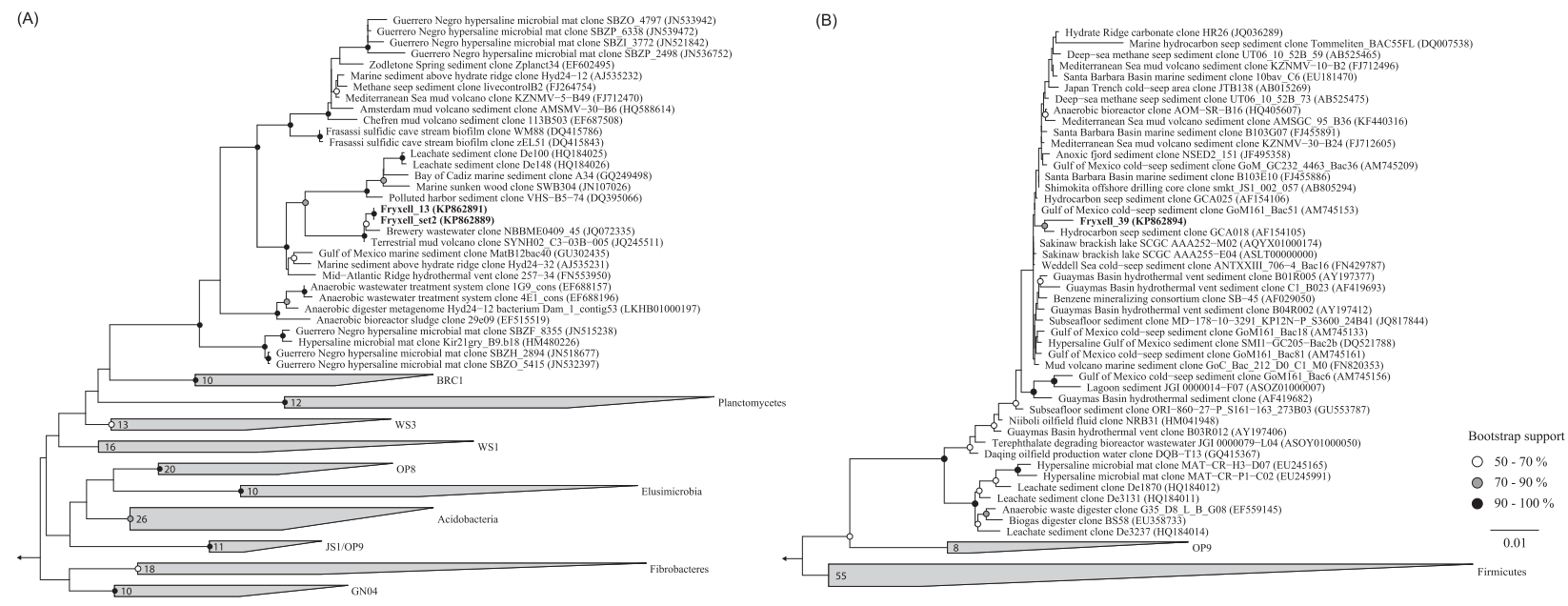

Fig. 6. Phylogenetic positions of candidate division (A) WM88 and (B) JS1 lineages obtained from $15 \mathrm{~m}$ depth of FRX. The trees were constructed using maximum likelihood analysis and sequences belonging to phylum Aquificae were used as outgroups. Scale bar indicates 0.01 substitutions per nucleotide position. 
(22.0\% and $67.5 \%$ of the total Gammaproteobacteria, respectively) indicates the existence of gammaproteobacterial lineages adapted to high salinity levels (Bowman et al., 2000). In addition, other phyla, including the Cyanobacteria, Verrucomicrobia and Planctomycetes, were also frequently observed, although their relative abundance varied greatly among lakes and depths, a finding consistent with previous results showing that these groups are common to and widespread in freshwater and marine ecosystems (Schlesner, 1994; Fuerst, 1995).

Fine-scale taxonomic analysis revealed that certain bacterial taxa are confined to or absent from specific water layers, particularly in the deepest suboxic layers of the lakes. The deepest layer (15 m) of Lake Fryxell was dominated by various uncultured bacterial groups belonging to candidate divisions JS1, WM88 and SAR406. Candidate division JS1 is commonly found in anoxic sedimentary systems, such as subsurface marine sediments (Parkes et al., 2007), methane hydrate-bearing sediments (Inagaki et al., 2006; Webster et al., 2007), deep marine sediments in the Antarctic (Carr et al., 2015) and sulfate-reducing sediments (Dhillon et al., 2003). Sediment enrichment and stable-isotope probing studies have shown that several JS1 members can utilise acetate and glucose under sulfate-reducing conditions (Webster et al., 2006, 2011); moreover, the abundance of JS1 in the bottom layer of Fryxell further suggests that certain JS1 members may be key bacterial representatives in the anoxic water columns of brackish lakes in addition to marine sediments.

Bacteria belonging to candidate division WM88 have been detected in various anoxic environments, including hydrothermal vents (Schauer et al., 2011), biofilms of sulfur-rich caves (Macalady et al., 2006) and hypersaline microbial mats (Harris et al., 2013). Sequences obtained from two WM88 clones (Fryxell_set2 and Fryxell_13) identified in the present study matched most closely to sequences deriving from bacteria collected from a terrestrial mud volcano (98.6-98.8\% 16S rRNA gene sequence similarities) (Cheng et al., 2012). These sequences were placed into a distinct clade that was separated from other WM88 lineages in the phylogenetic tree. The identical 16S rRNA gene sequences, designated as 'unclassified OTU B1', were also highly abundant in the upper layers of Fryxell sediment (relative abundance of $13.8-40.2 \%$ at a depth of $0-6 \mathrm{~cm}$ ) but virtually absent in the lower sediment layers (Tang, 2009). Relating those sequences to metabolic functions is limited at this stage due to a lack of information, but given their dominance in the bottom waters and sediments of Fryxell, they must play a significant role in this isolated ecosystem. The relative abundance of WM88 markedly increased in the $3.0 \mu \mathrm{m}$ size fraction compared to the $0.2 \mu \mathrm{m}$ fraction, an indication that this lineage may be present in particle-associated or aggregate forms; moreover, WM88 co-occurred with other bacterial phyla, including SAR406, Tenericutes, Candidatus Cloacamonas, OP3 and OP8, in this anoxic layer. The exclusive presence of these various candidate divisions at the $15 \mathrm{~m}$ depth in Fryxell may be associated with the unique biogeochemistry of the anoxic environment of this lake. Further research is necessary to deduce why these lineages occur together exclusively at this depth and how they have adapted to this unique environment.

There was clear separation of the classes of Firmicutes between East and West Lobe Bonney at a depth of $30 \mathrm{~m}$. Virgibacillus, which belong to class Bacilli, dominated the bottom layer of East Lobe Bonney (86.5\% of the total Bacilli), whereas several genera within class Clostridia were confined to the same depth in West Lobe Bonney. The dominance of Virgibacillus in East Lobe Bonney is consistent with previous research, in which it was reported that $35 \%$ of the $16 \mathrm{~S}$ rRNA gene clone library recovered from a depth of $25 \mathrm{~m}$ was linked to $V$. necropolis and $V$. salinus (after rematching reported sequences to those of recently updated species) (Glatz et al., 2006). Given the halotolerant or halophilic characteristics of cultured Virgibacillus spp., it would seem that these lineages have specifically adapted to the cold, halophilic environments of the lower water layers of East Lobe Bonney (Glatz et al., 2006). The suboxic layers of East Lobe Bonney are characterised by extreme levels of nitrous oxide $\left(\mathrm{N}_{2} \mathrm{O}\right)$ and a paucity of denitrification (Prisu et al., 1996), leading Priscu et al. (2008) to suggest that the high concentration of $\mathrm{N}_{2} \mathrm{O}$ in East Lobe Bonney might be a 'biogeochemical relict' produced by past microbial activity, a view based on the weak association between contemporary active nitrifiers and high concentrations of $\mathrm{N}_{2} \mathrm{O}$. Although there was no apparent evidence of any link between $\mathrm{N}_{2} \mathrm{O}$ and active microbes, our db-RDA results clearly showed that $\mathrm{NO}_{2}^{-}$ was an important factor in determining bacterial community structure at this depth.

The vast majority of Firmicutes collected from the bottom layer of West Lobe Bonney belong to an unknown genus of Clostridiales (EU245980_g; 76.5\% of the total Clostridia) and, to a much lesser extent, the genera Halocella (16.9\%) and Clostridium (13.0\%). Close relatives of the Clostridiales OTUs are frequently found in hypersaline microbial mats (Isenbarger et al., 2008; Harris et al., 2013). Halocella is known to be an obligately anaerobic halophile (Simankova et al., 1993) and many species of Clostridium are also common in hypersaline environments (Oren, 2005). The Clostridiales OTUs were shown to be associated with high $\mathrm{NH}_{4}^{+}$concentrations (Caskey and Tiedje, 1980) at depths of $17 \mathrm{~m}$ and $30 \mathrm{~m}$, as revealed by $\mathrm{db}-\mathrm{RDA}$. Alternatively, these Clostridiales genera may gain energy for growth by $\mathrm{Fe}^{2+}$ oxidation coupled with denitrification or dissimilatory nitrate reduction under anoxic conditions (Weber et al., 2006). West Lobe Bonney's deep waters have high ferrous iron concentrations resulting from 
the iron-rich input of the adjacent Taylor Glacier's Blood Falls (Mikucki and Priscu, 2007). In addition, Zetaproteobacteria, which were confined to $17 \mathrm{~m}$ and $30 \mathrm{~m}$ depths, are iron oxidizers under microaerobic conditions (Emerson et al., 2007). Thus, ferrous iron oxidation may be an important process in West Lobe Bonney, and the dependence of this process on nitrate availability should be investigated in the future. It is, however, unclear why distinct Firmicutes lineages dominate suboxic layers of East and West Lobe Bonney; possibly these niche-differentiated populations are the result of long-term adaptation to different selection pressures exerted by the particular anoxic environments within each lake.

In Lake Miers, Chlorobi sequences belonging to the genus Ignavibacterium $(98.2 \%$ of the total Chlorobi) were exclusively confined to the depth of $18 \mathrm{~m}$, and were not found in other depths or lakes surveyed in this study. Phylum Chlorobi (green sulfur bacteria) are known to be anaerobic photolithotrophs that typically inhabit the lowermost sections of photic environments, such as anoxic bottom layers of stratified lakes and microbial mats (lino et al., 2010; Comeau et al., 2012). A recent study conducted in Lake Fryxell demonstrated that Chlorobi bacteria are more abundant in deeper anoxic microbial mats than in the top mats (Jungblut et al., 2016). However, given the lack of previous bacterial research in Lake Miers, it is not clear that Ignavibacterium collected at $18 \mathrm{~m}$ are also dominant in anoxic microbial mats of equivalent depth. Class Ignavibacteria, including Ignavibacterium, form a deeply branching clade in Chlorobi phylogeny, and is distinguished from other photosynthetic clades by its reliance on chemoheterotrophy and lack of apparent photosynthetic metabolism, leading to proposals that this lineage be given its own phylum (lino et al., 2010; Podosokorskaya et al., 2013). In contrast to previous findings, bacterial production rates at this depth $(18 \mathrm{~m})$ make it hard to preclude the possibility of phototropic lineages within this group. The metabolic potential of this lineage in Lake Miers should be examined further by linking biogeochemical data with genomic evidence. Candidate division SR1 was found only in the bottom layers of lakes Miers and Fryxell, supporting its widespread occurrence in anoxic freshwater columns and sulfidogenic environments, although certain members were also detected in oxic layers (Borrel et al., 2010). There was little variation in community composition with depth throughout the water column of Lake Hoare, with no niche-specific lineages being confined to any particular segment of the water column.

Bacterial community composition in the upper layers of these lakes was relatively similar when compared to that of the bacterial communities at depths below the chemoclines, most likely due to comparable environmental conditions beneath the surface of perennially ice-covered lakes, and inputs from stream flow and the atmosphere into these lakes. Dieser et al. (2010) postulated that phylogenetic commonality among ice-embedded bacterial populations may result from environmental selection rather than processes such as dispersal and seeding from a single origin material, but the possibility of dispersal effects cannot be excluded here, as microbes are almost certainly transported in aeolian material carried by the wind throughout the MDVs (Michaud et al, 2012; Sabacka et al., 2012). The relatively similar biogeochemical properties among the upper water columns of these lakes supports this contention, and moreover corresponds with the finding that similar bacterial communities are found within the ice covers of Lakes Fryxell, Miers, Hoare and East and West Lobe Bonney (Gordon et al., 2000).

\section{Conclusions}

This study generated several novel results that may provide further insights into the ecology and evolution of bacteria inhabiting the ice-covered lakes of Antarctica. The deep waters beneath the chemoclines supported highly distinct communities both within each lake and among lakes, most likely due to spatial isolation and the unique geochemistry between lakes and within the strata of each individual lake. The presence of these niche-specific lineages provides evidence of strong specialisation of bacteria, which have uniquely adapted to isolated lake ecosystems over a long period of time. More integrated approaches, such as single-cell genomics and omics technologies, are needed to further examine the links between bacterial taxa and metabolic functions in these unique ecosystems.

\section{Acknowledgements}

This study was funded by PP13050, PM14030, PE15020 and PE17110 to Korea Polar Research Institute, and also granted by NSF-OPP $1115254,0838953,1027284$ and 0839075 . We would like to thank limnology team for environmental data and sample collection in 2012-2013 McMurdo long term ecological research (MCM LTER), and Dr. Joohan Lee of Korea Polar Research Institute for providing the site map of Dry Valleys.

\section{Conflict of interest}

The authors declare no conflict of interest

\section{References}

Anderson, M.J. (2001) A new method for non-parametric multivariate analysis of variance. Austral Ecol 26: 32-46.

Bell, R.A.I. (1967) Lake Miers, South Victoria Land, Antarctica. New Zeal J Geol Geophys 10: 540-556.

Berman, T. (1975) Size fractionation of natural aquatic populations associated with autotrophic and heterotrophic carbon uptake. Mar Biol 33: 215-220. 
Bielewicz, S., Bell, E.M., Kong, W., Friedberg, I., Priscu, J.C., and Morgan-Kiss, R.M. (2011) Protist diversity in a permanently ice-covered Antarctic lake during the polar night transition. ISME J 5: 1559-1564.

Borrel, G., Lehours, A.C., Bardot, C., Bailly, X., and Fonty, G. (2010) Members of candidate divisions OP11, OD1 and SR1 are widespread along the water column of the meromictic Lake Pavin (France). Arch Microbiol 192: 559-567.

Bowman, J.P., McCammon, S.A., Rea, S.M., and McMeekin, T.A. (2000) The microbial composition of three limnologically disparate hypersaline Antarctic lakes. FEMS Microbiol Ecol 183: 81-88.

Bowman, J.S., Vick-Majors, T.J., Morgan-Kiss, R., TakacsVesbach, C., Ducklow, H.W., and Priscu, J.C. (2016) Microbial community dynamics in two polar extremes: the lakes of the McMurdo Dry Valleys and the west Antarctic Peninsula marine ecosystem. Bioscience 66: 829-847.

Carr, S.A., Orcutt, B.N., Mandernack, K.W., and Spear, J.R. (2015) Abundant Atribacteria in deep marine sediment from the Adelie Basin, Antarctica. Front Microbiol 6: 872.

Caskey, W.H., and Tiedje, J.M. (1980) The reduction of nitrate to ammonium by a clostridium sp. Isolated from soil. J General Microbiol 119: 217-223.

Cheng, T.W., Chang, Y.H., Tang, S.L., Tseng, C.H., Chiang, P.W., Chang, K.T., et al. (2012) Metabolic stratification driven by surface and subsurface interactions in a terrestrial mud volcano. ISME J 6: 2280-2290.

Clarke, K.R., and Gorley, R.N. (2006) PRIMER v6: user manual/tutorial (Plymouth routines in multivariate ecological research). PRIMER-E Ltd: Plymouth, UK.

Clocksin, K.M., Jung, D.O., and Madigan, M.T. (2007) Coldactive chemoorganotrophic bacteria from permanently icecovered Lake Hoare, McMurdo Dry Valleys, Antarctica. Appl Environ Microbiol 73: 3077-3083.

Comeau, A.M., Harding, T., Galand, P.E., Vincent, W.F., and Lovejoy, C. (2012) Vertical distribution of microbial communities in a perennially stratified Arctic lake with saline, anoxic bottom waters. Sci Rep 2: 604.

R Core Team, (2013) R: A Language and Environment for Statistical Computing. Vienna: Austria R Found Stat Comput.

Darcy, J.L., Lynch, R.C., King, A.J., Robeson, M.S., and Schmidt, S.K. (2011) Global distribution of Polaromonas phylotypes-evidence for a highly successful dispersal capacity. PLoS One 6: e23742.

Dhillon, A., Teske, A., Dillon, J., Stahl, D.A., and Sogin, M.L. (2003) Molecular characterization of sulfate-reducing bacteria in the Guaymas Basin. Appl Environ Microbiol 69: 2765-2772.

Dieser, M., Nocker, A., Priscu, J.C., and Foreman, C.M. (2010) Viable microbes in ice: application of molecular assays to McMurdo Dry Valley lake ice communities. Antarct Sci 22: 470-476.

Dolhi, J.M., Teufel, A.G., Kong, W., and Morgan-Kiss, R.M. (2015) Diversity and spatial distribution of autotrophic communities within and between ice-covered Antarctic lakes (McMurdo Dry Valleys). Limnol Oceanogr 60: 977-991.

Dore, J.E., and Priscu, J.C. (2001) Phytoplankton phosphorus deficiency and alkaline phosphatase activity in the McMurdo Dry Valley lakes, Antarctica. Limnol Oceanogr 46: 1331-1346.
Emerson, D., Rentz, J.A., Lilburn, T.G., Davis, R.E., Aldrich, H., Chan, C., et al. (2007) A novel lineage of Proteobacteria involved in formation of marine Fe-oxidizing microbial mat communities. PLoS One 2: e667.

Feller, G., and Gerday, C. (2003) Psychrophilic enzymes:hot topics in cold adaptation. Nat Rev 1: 200-208.

Fierer, N., Jackson, J.A., Vilgalys, R., and Jackson, R.B. (2005) Assessment of soil microbial community structure by use of taxon-specific quantitative PCR assays. Appl Environ Microbiol 71: 4117-4120.

Fountain, A.G., Lyons, W.B., Burkins, M.B., Dana, G.L., Doran, P.T., Lewis, K.J., et al. (1999) Physical controls on the Taylor Valley ecosystem, Antarctica. Bioscience 49: 961-971.

Fuerst, J.A. (1995) The Planctomycetes: emerging models for microbial ecology; evolution and cell biology. Microbiology 141: 1493-1506.

Glatz, R.E., Lepp, P.W., Ward, B.B., and Francis, C.A. (2006) Planktonic microbial community composition across steep physical/chemical gradients in permanently ice-covered Lake Bonney, Antarctica. Geobiology 4: 53-67.

Glöckner, F.O., Fuchs, B.M., and Amann, R. (1999) Bacterioplankton compositions of lakes and oceans: a first comparison based on fluorescence in situ hybridization. Appl Environ Microbiol 65: 3721-3726.

Gordon, D.A., Priscu, J., and Giovannoni, S. (2000) Origin and phylogeny of microbes living in permanent Antarctic lake ice. Microb Ecol 39: 197-202.

Green, W.J., and Lyons, W.B. (2009) The saline lakes of the McMurdo Dry Valleys, Antarctica. Aquat Geochem 15: 321-348.

Harris, J.K., Caporaso, J.G., Walker, J.J., Spear, J.R., Gold, N.J., Robertson, C.E., et al. (2013) Phylogenetic stratigraphy in the Guerrero Negro hypersaline microbial mat. ISME J: 50-60.

Hsieh, T.C., Ma, K.H., and Chao, A. (2016) iNEXT: an R package for rarefaction and extrapolation of species diversity (Hill numbers). Methods Ecol Evol 7: 1451-1456.

lino, T., Mori, K., Uchino, Y., Nakagawa, T., Harayama, S., and Suzuki, K. (2010) Ignavibacterium album gen. nov., sp. nov., a moderately thermophilic anaerobic bacterium isolated from microbial mats at a terrestrial hot spring and proposal of Ignavibacteria classis nov., for a novel lineage at the periphery of green sulfur bacteria. Int J Syst Evol Microbiol 60: 1376-1382.

Inagaki, F., Nunoura, T., Nakagawa, S., Teske, A., Lever, M., Lauer, A., et al. (2006) Biogeographical distribution and diversity of microbes in methane hydrate-bearing deep marine sediments on the Pacific Ocean Margin. Proc Natl Acad Sci USA 103: 2815-2820.

Isenbarger, T.A., Finney, M., Ríos-Velázquez, C., Handelsman, J., and Ruvkun, G. (2008) Miniprimer PCR, a new lens for viewing the microbial world. Appl Environ Microbiol 74: 840-849.

Jeon, Y.S., Chung, H., Park, S., Hur, I., Lee, J.H., and Chun, J. (2005) jPHYDIT: a JAVA-based integrated environment for molecular phylogeny of ribosomal RNA sequences. Bioinformatics 21: 3171-3173.

Jungblut, A.D., Hawes, I., Mackey, T.J., Krusor, M., Doran, P.T., Sumner, D.Y., et al. (2016) Microbial mat communities along an oxygen gradient in a perennially ice-covered Antarctic lake. Appl Environ Microbiol 82: 620-630. 
Karr, E.A., Sattley, W.M., Jung, D.O., Madigan, M.T., and Achenbach, L.A. (2003) Remarkable diversity of phototrophic purple bacteria in a permanently frozen Antarctic lake. Appl Environ Microbiol 69: 4910-4914.

Karr, E.A., Sattley, W.M., Rice, M.R., Jung, D.O., Madigan, M.T., and Achenbach, L.A. (2005) Diversity and distribution of sulfate-reducing bacteria in permanently frozen Lake Fryxell, McMurdo Dry Valleys, Antarctica. Appl Environ Microbiol 71: 6353-6359.

Kim, O.S., Cho, Y.J., Lee, K., Yoon, S.H., Kim, M., Na, H., et al. (2012) Introducing EzTaxon-e: a prokaryotic 16S rRNA gene sequence database with phylotypes that represent uncultured species. Int J Syst Evol Microbiol 62: 716-721.

Kirkegaard, R.H., Dueholm, M.S., Mcilroy, S.J., Nierychol, M., Karst, S.M., Albertsen, M., et al. (2016) Genomic insights into members of the candidate phylum Hyd24-12 common in mesophilic anaerobic digesters. ISME J 10: 2352-2364.

Kong, W., Dolhi, J.M., Chiuchiolo, A., Priscu, J., and MorganKiss, R. (2012) Evidence of form II RubisCO (cbbM) in a perennially ice-covered Antarctic lake. FEMS Microbiol Ecol 82: 491-500.

Kong, W., Li, W., Prášil, O., Romancova, I., and Morgan-Kiss, R.M. (2014) An integrated study of photochemical function and expression of a key photochemical gene (psbA) in photosynthetic communities of Lake Bonney (McMurdo Dry Valleys, Antarctica). FEMS Microbiol Ecol 89: 293-302.

Lane, D.J. (1991) 16S/23S rRNA sequencing. In Nucleic Acid Techniques in Bacterial Systematics. Stackebrandt, E., and Goodfellow, M. (eds). Chichester: Wiley, pp. 115-175.

Lee, P.A., Mikucki, J.A., Foreman, C.M., Priscu, J.C., Ditullio, G.R., Riseman, S.F., et al. (2004) Thermodynamic constraints on microbially mediated processes in lakes of the McMurdo Dry Valleys, Antarctica. Geomicrobiol J 21: 221-237.

Legendre, P., and Anderson, M.J. (1999) Distance-based redundancy analysis: testing multispecies responses in multifactorial ecological experiments. Ecol Monogr 69: $1-24$.

Li, W., Podar, M., and Morgan-Kiss, R.M. (2016) Ultrastructural and single-cell-level characterization reveals metabolic versatility in a microbial eukaryote community from an Ice-covered Antarctic Lake. Appl Environ Microbiol 82: 3659-3670.

Lizotte, M.P., and Priscu, J.C. (1994) Natural fluorescence and quantum yields in vertically stationary phytoplankton from perennially ice-covered lakes. Limnol Oceanogr 39: 1399-1410.

Lyons, W., Tyler, S., Wharton, R., Mcknight, D., and Vaughn, B. (1998) A late Holocene desiccation of Lake Hoare and Lake Fryxell, McMurdo Dry Valleys, Antarctica. Antarc Sci 10: 247-256.

Macalady, J.L., Lyon, E.H., Koffman, B., Albertson, L.K., Meyer, K., Galdenzi, S., et al. (2006) Dominant microbial populations in limestone-corroding stream biofilms, Frasassi cave system, Italy. Appl Environ Microbiol 72: 5596-5609.

Michaud, A.B., Šabacká, M., and Priscu, J.C. (2012) Cyanobacterial diversity across landscape units in a polar desert: Taylor Valley, Antarctica. FEMS Microbiol Ecol 82: 268-278.

Michaud, L., Caruso, C., Mangano, S., Interdonato, F., Bruni, V., and Giudice, A.L. (2012) Predominance of Flavobacterium, Pseudomonas, and Polaromonas within the prokaryotic community of freshwater shallow lakes in the northern Victoria Land, East Antarctica. FEMS Microbiol Ecol 82: 391-404.

Mikucki, J.A., and Priscu, J.C. (2007) Bacterial diversity associated with Blood Falls, a subglacial outflow from the Taylor Glacier, Antarctica. Appl Environ Microbiol 73: 4029-4039.

Morgan-Kiss, R., Lizotte, M., Kong, W., and Priscu, J.C. (2016) Photoadaptation to the polar night by phytoplankton in a permanently ice-covered Antarctic lake. Limnol Oceanogr 61: 3-13.

Nadkarni, M.A., Martin, F.E., Jacques, N.A., and Hunter, N. (2002) Determination of bacterial load by real-time PCR using a broad-range (universal) probe and primers set. Microbiology 148: 257-266.

Newton, R.J., Jones, S.E., Eiler, A., McMahon, K.D., and Bertilsson, S. (2011) A guide to the natural history of freshwater lake bacteria. Microbiol Mol Biol Rev 75: 14-49.

Oh, J., Kim, B.K., Cho, W.S., Hong, S.G., and Kim, K.M. (2012) PyroTrimmer: a software with GUI for pre-processing 454 amplicon sequences. J Microbiol 50: 766-769.

Oksanen, J., Blanchet, F.G., Kindt, R., Legendre, P., Minchin, P.R., O'hara, R.B., et al. (2015) vegan: Community Ecology Package. R package version 2.2-1 [WWW document]. URL http://CRAN.R-project.org/package= vegan .

Oren, A. (2005) Halophilic Clstridia. In Handbook on Clostridia. Dürre, P. (ed). Boca Raton: CRC press, pp. 942-966.

Parkes, R.J., Cragg, B.A., Banning, N., Brock, F., Webster, G., Fry, J.C., et al. (2007) Biogeochemistry and biodiversity of methane cycling in subsurface marine sediments (Skagerrak, Denmark). Environ Microbiol 9: 1146-1161.

Podosokorskaya, O.A., Kadnikov, V.V., Gavrilov, S.N., Mardanov, A.V., Merkel, A.Y., Karnachuk, O.V., et al. (2013) Characterization of Melioribacter roseus gen. nov., sp. nov., a novel facultatively anaerobic thermophilic cellulolytic bacterium from the class Ignavibacteria, and a proposal of a novel bacterial phylum Ignavibacteriae. Environ Microbiol 15: 1759-1771.

Poreda, R.J., Hunt, A.G., Lyons, W.B., and Welch, K.A. (2004) The helium isotopic chemistry of Lake Bonney, Taylor Valley, Antarctica: timing of late holocene climate change in Antarctica. Aquat Geochem 10: 353-371.

Priscu, J.C. (1995) Phytoplankton nutrient deficiency in lakes of the McMurdo Dry Valleys, Antarctica. Freshw Biol 34: 215227.

Priscu, J.C. (1997) The biogeochemistry of nitrous oxide in permanently ice-covered lakes of the McMurdo Dry Valleys, Antarctica. Glob Chang Biol 3: 301-315.

Priscu, J.C., Downes, M.T., and McKay, C.P. (1996) Extreme supersaturation of nitrous oxide in a poorly ventilated Antarctic lake. Limnol Oceanogr 41: 1544-1551.

Priscu, J.C., Christner, B.C., Dore, J.E., Popp, B.N., Casciotti, K.L., and Lyons, W.B. (2008) Supersaturated N2O in a perennially ice-covered Antarctic lake: molecular and stable isotopic evidence for a biogeochemical relict. Limnol Oceanogr 53: 2439-2450.

Pruesse, E., Peplies, J., and Glöckner, F.O. (2012) SINA: accurate high-throughput multiple sequence alignment of ribosomal RNA genes. Bioinformatics 28: 1823-1829.

Sabacka, M., Priscu, J.C., Basagic, H.J., Fountain, A.G., Wall, D.H., Virginia, R.A., et al. (2012) Aeolian flux of biotic and 
abiotic material in Taylor Valley, Antarctica. Geomorphology 155-156: 102-111.

Sattley, W.M., and Madigan, M.T. (2006) Isolation, characterization, and ecology of cold-active, chemolithotrophic, sulfuroxidizing bacteria from perennially ice-covered Lake Fryxell, Antarctica. Appl Environ Microbiol 72: 5562-5568.

Schauer, R., Røy, H., Augustin, N., Gennerich, H., Peters, M., Wenzhoefer, F., et al. (2011) Bacterial sulfur cycling shapes microbial communities in surface sediments of an ultramafic hydrothermal vent field. Environ Microbiol 13: 2633-2648.

Schlesner, H. (1994) The development of media suitable for the microorganisms morphologically resembling Planctomyces spp., Pirellula spp., and other Planctomycetales from various aquatic habitats using dilute media. Syst Appl Microbiol 17: 135-145.

Schloss, P.D., Westcott, S.L., Ryabin, T., Hall, J.R., Hartmann, M., Hollister, E.B., et al. (2009) Introducing mothur: opensource, platform-independent, community-supported software for describing and comparing microbial communities. Appl Environ Microbiol 75: 7537-7541.

Simankova, M.V., Chernych, N.A., Osipov, G.A., and Zavarzin, G.A. (1993) Halocella cellulolytica gen. nov., sp. nov., a new obligately anaerobic, halophilic, cellulolytic bacterium. Syst Appl Microbiol 16: 385-389.

Simon, M. (1985) Specific uptake rates of amino acids by attached and free-living bacteria in a mesotrophic lake. Appl Environ Microbiol 49: 1254-1259.

Spigel, R.H., and Priscu, J.C. (1998) Physical limnology of the McMurdo Dry Valleys lakes. In Ecosystem Dynamics in a Polar Desert: The McMurdo Dry Valleys, Antarctica. Antarctic Research Series, Vol. 72. Priscu, J. C. (ed.). Washington, DC, USA: American Geophysical Union.

Smith, R.L., Miller, L.G., and Howes, B. (1993) The geochemistry of methane in Lake Fryxell, an amictic, permanently ice-covered, Antarctic lake. Biogeochemistry 21: 95-115.

Stamatakis, A. (2014) RAxML version 8: a tool for phylogenetic analysis and post-analysis of large phylogenies. Bioinformatics 30: 1312-1313.

Takacs, C.D., and Priscu, J.C. (1998) Bacterioplankton dynamics in the McMurdo Dry Valley Lakes, Antarctica: production and biomass loss over four seasons. Microb Ecol 36: 239-250.

Takahashi, S., Tomita, J., Nishioka, K., Hisada, T., and Nishijima, M. (2014) Development of a prokaryotic universal primer for simultaneous analysis of bacteria and archaea using next-generation sequencing. PLoS One 9: e105592.

Tang, C. (2009) Microbial diversity studies in sediments of perennially ice-covered lakes, McMurdo Dry Valleys, Antarctica. (Doctoral dissertation) University of California, Riverside.

Tang, C., Madigan, M.T., and Lanoil, B. (2013) Bacterial and archaeal diversity in sediments of West Lake Bonney, McMurdo Dry Valleys, Antarctica. Appl Environ Microbiol 79: 1034-1038.

Vick-Majors, T.J., Priscu, J.C., and Amaral-Zettler, L.A. (2013) Modular community structure suggests metabolic plasticity during the transition to polar night in ice-covered Antarctic lakes. ISME J 8: 778-789.

Weber, K.A., Achenbach, L.A., and Coates, J.D. (2006) Microorganisms pumping iron: anaerobic microbial iron oxidation and reduction. Nat Rev Microbiol 4: 752-764.
Webster, G., Watt, L.C., Rinna, J., Fry, J.C., Evershed, R.P., Parkes, R.J., et al. (2006) A comparison of stable-isotope probing of DNA and phospholipid fatty acids to study prokaryotic functional diversity in sulfate-reducing marine sediment enrichment slurries. Environ Microbiol 8: 1575-1589.

Webster, G., Yarram, L., Freese, E., Köster, J., Sass, H., Parkes, R.J., et al. (2007) Distribution of candidate division JS1 and other Bacteria in tidal sediments of the German Wadden Sea using targeted 16S rRNA gene PCR-DGGE. FEMS Microbiol Ecol 62: 78-89.

Webster, G., Sass, H., Cragg, B.A., Gorra, R., Knab, N.J., Green, C.J., et al. (2011) Enrichment and cultivation of prokaryotes associated with the sulphate-methane transition zone of diffusion-controlled sediments of Aarhus Bay, Denmark, under heterotrophic conditions. FEMS Microbiol Ecol 77: 248-263.

\section{Supporting information}

Additional Supporting Information may be found in the online version of this article at the publisher's web-site:

Table S1. Physicochemical and biological characteristics at the sampling depths for each lake.

Table S2. Ion chemistry at the sampling depths for each lake.

Table S3. Summary of pyrosequencing results and estimated diversity indices.

Table S4. Relative abundance of other bacterial phyla within each lake.

Table S5. Heat map representing relative abundance of top 10 major OTUs in each depth and their taxonomic information.

Table S6. BLAST results of candidate division WM88 and JS1 clone sequences against Genbank database

Fig. S1. Sample-size-based rarefaction and extrapolation curves for Hill numbers of $q=0,1,2$ : (A) FRX, (B) MIE, (C) ELB, (D) WLB and (E) HOR. In each plot, Hill numbers are shown as $q=0$ (left panel), $q=1$ (middle panel) and $q=2$ (right panel), and shaded regions represent $95 \%$ confidence intervals.

Fig. S2. db-RDA plots of 'best' model selection by DISTLM for each number of environmental variables. (A) FRX; there is multicollinearity between $\mathrm{BP}, \mathrm{DO}$ and $\mathrm{NH}_{4}^{+}(|r|>0.93)$, and between $\mathrm{SO}_{4}^{2-}$, depth, conductivity, DIC, DOC, $\mathrm{Na}, \mathrm{K}, \mathrm{Mg}, \mathrm{Ca}$ and $\mathrm{Cl}(\mid r$ $>0.91$ ), (B) MIE; between depth, conductivity, DO, DIC, Mg, $\mathrm{Ca}, \mathrm{K}$ and $\mathrm{F}(|r|>0.91)$, between temperature, $\mathrm{Na}$ and $\mathrm{Cl}(\mid r$ $>0.97)$, between PPR and AmbPAR $(r=0.98)$, and between $\mathrm{SO}_{4}^{2-}$ and $\mathrm{BP}(r=-0.97)$, (C) ELB; between $\mathrm{SO}_{4}^{2-}$, conductivity, depth, $\mathrm{DIC}, \mathrm{NO}_{3}^{-}, \mathrm{Na}, \mathrm{K}, \mathrm{Mg}, \mathrm{Ca}, \mathrm{Cl}$ and UwPAR $(|r|>0.91)$, and between $\mathrm{NO}_{2}^{-}$, DOC and $\mathrm{Br}(|r|>0.96)$, (D) WLB; between $\mathrm{SO}_{4}^{2-}$, conductivity, $\mathrm{pH}, \mathrm{DIC}$, depth, $\mathrm{Na}, \mathrm{K}, \mathrm{Mg}, \mathrm{Ca}$ and $\mathrm{Cl}(\mid r$ $>0.93)$, and between $\mathrm{NH}_{4}^{+}, \mathrm{DO}$ and $\mathrm{Br}(|r|>0.91)$, and (E) $\mathrm{HOR}$; between $\mathrm{SO}_{4}^{2-}$, conductivity, $\mathrm{NO}_{2}^{-}$, DOC, DIC, $\mathrm{Na}, \mathrm{K}, \mathrm{Mg}$, $\mathrm{Ca}, \mathrm{Cl}$ and $\mathrm{F}(|r|>0.93)$, and between depth, temperature, UwPAR and AmbPAR $(|r|>0.91)$. Closed circles and triangles represent November and December samples, respectively. 